Instructions for authors, subscriptions and further details:

http://qre.hipatiapress.com

\title{
Self-Advocates with Intellectual Disability about Their Work as Social Educators - a Qualitative Polish Study
}

Iwona Nowakowska ${ }^{1}$ \& Ewa Pisula ${ }^{2}$

1) Institute of Psychology, Maria Grzegorzewska University, Poland.

2) Faculty of Psychology, University of Warsaw, Poland.

Date of publication: February $28^{\text {th }}, 2021$

Edition period: February 2021 - June 2021

To cite this article: Nowakowska, I., \& Pisula, E. (2021). Self-Advocates with Intellectual Disability about Their Work as Social Educators - a Qualitative Polish Study. Qualitative Research in Education, 10(1), 1-30. doi:10.17583/qre.2021.6063

To link this article: $\mathrm{http}: / / d x . d o i . o r g / 10.17583 / q r e .2021 .6063$

\section{PLEASE SCROLL DOWN FOR ARTICLE}

The terms and conditions of use are related to the Open Journal System and to Creative Commons Attribution License (CC-BY). 


\section{Self-Advocates with Intellectual Disability about Their Work as Social Educators - a Qualitative Polish Study}

Iwona Nowakowska

Maria Grzegorzewska University

Institute of Psychology
Ewa Pisula

University of Warsaw

Faculty of Psychology

(Received: 30 June 2020; Accepted: 17 February 2021; Published: 28 February 2021)

\section{Abstract}

The paper presents the opinions of self-advocates with mild intellectual disability about their work as social educators - public self-advocates raising disability awareness. Six semi-structured individual interviews were conducted. Data was analyzed within the framework of Interpretative Phenomenological Analysis. The themes which emerged from the interviews comprise: the motives of educators to work as self-advocates, opportunities to gain new skills and to raise public awareness about disability given by this activity, the difficulties they experience being social educators and ways to overcome them, the meaning of self-advocacy in their lives as well as the readiness to recommend this work to other people with disability. The gathered data suggests that, according to the self-advocates, being a social educator enhances the social status of self-advocates. It also provides an opportunity to develop skills, new social roles and sometimes positive identities, which is in line with the assumptions of the theoretical models of self-advocacy.

Keywords: disability awareness, intellectual disability, interpretative phenomenological analysis, self-advocacy, semi-structured interview 


\section{Autogestores con Discapacidad Intelectual sobre su Trabajo como Educadores Sociales - un Estudio Cualitativo Polaco}

Iwona Nowakowska

Maria Grzegorzewska University

Institute of Psychology
Ewa Pisula

University of Warsaw

Faculty of Psychology

(Recibido: 30 de junio de 2020; Aceptado: 17 de febrero de 2021; Publicado: 28 de febrero de 2021)

\section{Resumen}

El artículo presenta las opiniones de los autogestores con discapacidad intelectual leve sobre su trabajo como educadores sociales - autogestores públicos que sensibilizan sobre la discapacidad. Se realizaron seis entrevistas individuales semiestructuradas. Los datos se analizaron en el marco del Análisis Fenomenológico Interpretativo. Los temas que surgieron de las entrevistas comprenden: los motivos de los educadores para trabajar como autodefensores, las oportunidades de adquirir nuevas habilidades y de sensibilizar al público sobre la discapacidad que ofrece esta actividad, las dificultades que experimentan como educadores sociales y las formas de superarlas, el significado de la autodefensa en sus vidas, así como la disposición a recomendar este trabajo a otras personas con discapacidad. Los datos recogidos sugieren que, según los autogestores, ser educador social mejora el estatus social de los autogestores. También proporciona una oportunidad para desarrollar habilidades, nuevos roles sociales y, en ocasiones, identidades positivas, lo que coincide con los supuestos de los modelos teóricos de la autodefensa.

Palabras clave: conciencia de la discapacidad, discapacidad intelectual, análisis fenomenológico interpretativo, autodefensa, entrevista semiestructurada. 
elf-advocacy is a phenomenon of individuals with disability acting independently for their own interests (Stuntzner \& Hartley, 2015), and expressing own opinion about all aspects of life (Azzopardi-Lane $\&$ Callus, 2015). It also gives them opportunity to take control over their own life, to become a fully fledged partner in social interactions, to talk about their problems, needs and rights, to learn making decisions (e.g., Downing et al., 2007; Test et al., 2005). It is however not only the individual resistance to oppression from the majority group (Petri et al., 2017), but is also defined as a collective voice of people with disability (Walmsley, 2014), and is a part of the disability rights movement (Degener, 2016; Goodley, 2011).

Ryan and Griffiths (2015) distinguished three forms of self-advocacy: individual - when people act for their own interests, making independent everyday decisions; group - when individuals gather to act for a common cause; public - when people educate others and raise awareness about the problems of own social group. For the latter form, the idea of self-advocates as agents educating the public by means of direct contact is congruent with the contact hypothesis (Allport, 1954). According to it, prejudice (a cognitive component of attitude, which is modifiable) might be reduced thanks to contact with representatives of a minority group with representatives of a majority group. To achieve that, contact should be based on cooperation to attain a common goal, and the interaction participants ought to have equal status. The effect of attitude change is enhanced when the contact has institutional support. Prejudice can be lowered only when they are not deeply rooted in the personality structure of a person. Importantly, on the one hand contact, with a minority group has the potential to lower prejudice, but on the other hand prejudice lowers the frequency of intergroup contact (Binder et al. 2009).

Apart from the social impact it may have, self-advocacy supports the development of various competences; however, this activity might be difficult because of the emotions related to discussing, for example, experiences of discrimination, bullying, or physical aggression (Ryan \& Griffiths, 2015). To overcome this, the quality of the relationship and trust between the members of the self-advocacy platform or group and the supporting staff is crucial. The support of the social environment of people with intellectual disabilities (ID) is crucial to promote self-determination (Nota et al., 2007; Wehmeyer \& Garner, 2003). Excessive control and awaiting compliance with the rules and ideas of others instead of encouraging 
people with ID to take initiative may result in their passivity. Friendly support from the environment helps people with ID to achieve autonomy and independence, and to realize their right to self-determination.

People with ID can benefit greatly by learning the skills necessary to selfadvocate, as they experience many limitations in exercising their rights to independence and autonomy (Wullink et al., 2009). Self-advocacy, especially when performed within organizational settings, ought to support people in implementing these rights in their lives while eliminating the "tokenism" (Kanter, 1977) - making only symbolic efforts to include people from the minority group (e.g., people with disabilities) in an activity managed by organizations or institutions dominated by people from the mainstream. Tokenism may be linked to limited access to real decision-making in selfadvocacy groups (Beckwith et al., 2016; Friedman et al., 2016; Petri et al., 2017). It is important to investigate to what degree self-advocacy groups acknowledge the issue of real participation of their members to adequately assess the impact it may have on their personal development.

Anderson and Bigby (2017) created a theoretical model of self-advocacy, gathering the important functions it has and the opportunities which might be gained. Self-advocacy creates possibilities such as having power and status, speaking out, being a friend and having friends, having fun and being happy, helping others, and relieving boredom. These opportunities result in greater confidence and engagement with one's own life. A person might also build a positive identity, develop a sense of self and strengthen self-determination, sense of empowerment, and resilience (Clarke et al., 2015). Data from interviews with self-advocates with ID suggest that the abovementioned benefits might be gained from such activity (Anderson \& Bigby, 2017; Caldwell, 2011; Gilmartin \& Slevin, 2010; Hall, 2005; McNally, 2003; for the recent systematic reviews see also: Fenn \& Scior, 2019; Tilley et al., 2020). Given the relative independence of the Anderson \& Bigby's model from cultural contexts and the fact that the theory is grounded in the real experiences of people with ID from various self-advocacy groups, this model might serve as an important reference point when discussing experiences of self-advocates worldwide.

The idea of organized self-advocacy began to spread worldwide in the 1960s (Nirje, 1972; Pennell, 2001), initiating the establishment of selfadvocacy groups in various countries, however, at a different pace for various countries (Henderson \& Bigby, 2016). In Poland, a pioneer of self-advocacy 
was the Polish Association for Persons with Intellectual Disability (Polish: Polskie Stowarzyszenie na Rzecz Osób z Niepełnosprawnością Intelektualną, PSONI) (e.g., Żyta \& Ćwirynkało, 2016). Apart from PSONI, very few self-advocacy organizations for people with ID exist in Poland, e,g. the Open Door Association (Stowarzyszenie Otwarte Drzwi), and the data about the perspectives of Polish self-advocates on their work are very scarce, gathered either by the professional staff from a particular institution (e.g., Jaglińska, 2018) or focusing on the meaning of self-advocacy and the lived experiences of people with a disability (Żyta \& Ćwirynkało, 2016) or some legal considerations (Firkowska-Mankiewicz \& Szeroczyńska, 2009). In Poland, most often the self-advocacy groups for people with ID function within the scope of nongovernmental organizations. One of the reasons for this might be the fact that there is relatively low social acceptance of people with ID in Poland compared to people with other forms of disability and the still present belief in Poland that people with ID have very limited capability to cope independently and take initiative in their lives (see: Kowalska \& Winnicka, 2013; Maison \& Rudzińska-Wojciechowska, 2011).

Self-advocacy actions are popular worldwide with clear social and psychological impact on the lives of people with intellectual disability (for a review see Fenn \& Scior, 2019). However, the perspective of the selfadvocates on their work is still to be explored. Importantly, investigating specific, homogeneous groups of self-advocates is worthwhile, given that every self-advocacy group has its specificity and functions in the context of own country, which needs to be taken into account. The research question is what self-advocates from a Polish organization promoting being "social educators" as a form of empowerment of people with intellectual disabilities reckon about their specific work and its impact?

\section{The Current Study}

The current study was performed on the basis of a self-advocacy project performed by one of the largest nongovernmental organizations supporting people with a disability in Warsaw, Poland. The organization's mission is to combat social exclusion by supporting diverse social groups threatened with social exclusion (people with disabilities, those in homelessness crisis, unemployed, youth from problematic neighborhoods, and others). It offers a wide variety of activities supporting the development, education, 
rehabilitation and social functioning of the abovementioned groups, e.g. occupational therapy, job coaching, self-help groups, volunteering and selfadvocacy opportunities. The staff consists of various specialists, mainly in psychology, special education, career and personal coaching. The organization is financed by donations, private sponsors, state and nongovernmental grants. It conducts many original projects aimed to empower persons with intellectual disabilities. One of these projects engaged self-advocates who conducted anti-discriminatory workshops for various audiences. Due to confidentiality issues and participants' protection, we do not provide the name of the organization and later refer to it in this paper as "the Organization".

Exploring the experiences of people with ID requires appropriate preparation and methods (Beail \& Williams, 2014; Iacono, 2006; Monteleone, 2017). Some opinions of self-advocates have been gathered by the Organization, but no study designed and conducted by independent researchers has been performed so far.

Analysis of the opinions of Polish self-advocates with ID may provide information relevant to this field, which is also of interest to researchers and practitioners working with people with ID in other countries. In order to answer the research question, semi-structured interviews were conducted. Design and analysis of the interviews were based on the Interpretative Phenomenological Analysis framework (IPA) (Smith et al., 1999; 2009), taking into account recent guidelines by Rose et al. (2019) about using IPA in research with people with ID.

\section{Method}

\section{The Self-Advocacy Project Background}

Prior to the study, the Organization had run a self-advocacy project financed by external grants. For two years prior to the study the Organization had been receiving funding from a major state organization in Poland which supports the development of civic initiatives.

Within the project, self-advocates with disabilities, the vast majority of whom had mild ID and/or experience mental health crises, conducted workshops for various target groups: pupils of mainstream and special schools; university students; parents of children with and without disability, 
office workers, potential work colleagues and employers of people with disability, people with chronic illnesses, as well as inmates. Thanks to the external funds, the self-advocates had received a small amount of financial remuneration. The remuneration was granted after conducting each of the workshops.

Since the first run of the project in 2016, 15 educators in total have been involved in conducting workshops. During the first year when the project was delivered, 387 people in total participated in the workshops (data from the Organization website).

Becoming a social educator in the Organization required people with disability to take part in a recruitment phase, followed by several courses on self-presentation and coping in difficult social situations. The future selfadvocates must have also obtained credit for "training samples," during which they could verify their skills in leading a meeting in a safe environment of other social educators and the Organization staff members. The recruitment was managed mainly by the professional staff of the Organization.

The workshops conducted by the social educators aimed at changing attitudes, under the assumption that personal contact would be beneficial to intergroup relations. Answering to the contact hypothesis (Allport, 1954), the project aims to maximize the personal contact between self-advocates and participants, introduce opportunities for cooperation, and take place in institutional contexts (e.g. in schools or workplaces). The scenarios of the workshops within the project were developed mainly by the Organization's professional staff, with openness to alterations made by the self-advocates themselves.

A typical workshop consisted of two 90 -minute parts. The first was a group discussion. The self-advocates talked about their experiences and difficulties associated with disability and social relationships. Next, the workshop participants discussed the perception of disability. The session finished with a film presenting the supported employment offered to people with ID. The second part of the workshop was an art meeting held a few days after the discussion meeting. The participants prepared works of art, in most cases linocuts, inspired by the theme "What do I and people with disability have in common?" Self-advocates (not necessarily the same as during the first meeting) were present during this part. They were familiar with the 
linocuts technique, so they can advise students and help them in preparing their artwork.

It should be noted that the professional staff involved in the project was providing extensive support to its participants, including the presence of the Organization staff at self-advocacy group meetings and at project workshops. The staff members moderated the discussion between the participants and the self-advocates, keep the workshop going when the self-advocates did not initiate new interactions with the audience, and helped the self-advocates manage the group of workshop recipients. During the art meeting, they provided instructions for the audience and served as technical support when making the linocuts. Therefore, the social educators did not control the group independently and did not take full responsibility for their actions. A probable reason for such a small degree of involvement of people with ID in the project design is that the project was financed by grant competition, which requires following success strategies, deadlines and strict rules in writing grant proposals. That might have led the Organization to rely mostly on the professional staff rather than the self-advocates themselves.

\section{Interview Schedule}

Due to the uniqueness of the studied phenomenon - self-perception of selfadvocates with ID regarding their activity as social educators - no previous research containing a similar interview schedule was found. However, in order to prepare the semi-structured set of topics to be discussed, the authors drew inspiration from qualitative studies on self-advocacy experiences of people with ID (Anderson \& Bigby, 2017; Caldwell 2011; Gilmartin \& Slevin, 2010). Moreover, the questions were designed following the suggestions for semi-structured interviewing of people with ID by Hollomotz (2018) in as plain and accessible language as possible.

The interview schedule was as follows:

1. Why did you become a social educator?

2. How did it happen that you became a social educator? Follow-up questions: How did you learn about this opportunity? Was there someone who encouraged you to participate?

3. What is the most important for you in being a social educator?

4. Are there any difficulties in being a social educator? 
5. What have you learned thanks to being a social educator? Follow-up question: Has something in your life changed thanks to that?

6. Would you encourage other people with disability to become a social educator? Why?

\section{Recruitment of Participants}

The project coordinator from the Organization provided support in the recruitment of participants. The first author of the study met with a group of eight social educators to present the planned research, get to know the potential participants, and answer their questions.

The coordinator invited by word of mouth all of the 10 social educators engaged at the time in the project to participate in the study. All of the people who were the social educators, regardless of the level of their experience, who volunteered to take part were invited to the interviews. Seven people participated in the study. However, one of the conducted interviews was excluded from this report due to the different character of the disability of the participant (hearing impairment and pemphigus).

\section{Data Collection}

The project coordinator was present at the Organization on the day of conducting the interviews to introduce the interviewer (the first author of the manuscript) to the interviewees, and along with the interviewer, to answer questions that occurred before the study and to instill a pleasant, safe atmosphere.

The interviews were conducted individually in a separate room at the Organization. At first, the participants were informed again about the aims of the study, the topics to be mentioned, the need to record the audio, and the possible usage of the transcription of the material (analysis for research purposes and publication). Emphasis was placed on anonymity, confidentiality of the audio recordings. and the right to opt out of the study. After ensuring that each participant understood the conditions of participation and provides an initial agreement, a written consent form, in easy to read language, taking into account the issues of informed consent to participate in research (Arscott et al., 1998; Iacono, 2006) was distributed to 
be signed by the participant. The interviews lasted between 30 and 45 minutes each.

All of the participants communicated without external support technologies; all were native users of Polish language. The respondents were given the necessary time to answer the questions fully. In the case of articulation problems, the answers were paraphrased and clarified with the respondent when necessary until a confirmation from the respondent that they were understood correctly was obtained. None of the respondents withdrew from the study.

Afterwards, each of the interviews was listened to and transcribed verbatim, with regard given to important non-verbal aspects of the interview.

The participants were six social educators ( 3 females, 3 males), aged 2535 years $(M=28, S D=4.43)$. Five of the participants had a diagnosis of mild ID, one had other diagnoses (epilepsy and memory deficits due to a stroke) and participated in activities at the Organization together with people with mild ID. All of the participants lived in the same city of more than 500,000 inhabitants. At the time of the interviews, they all had two years of experience as members of the project team.

Following the suggestion by Rose et al. (2019), for the sake of anonymity and easiness of tracking information, the participants in this report were assigned pseudonyms not connected in any way to their real names. Table 1 presents the pseudonyms and additional data about the participants (gender, additional diagnoses, employment status, relationship status). 
Table 1.

Pseudonyms and characteristics of the participants

\begin{tabular}{|c|c|c|c|c|}
\hline Pseudonym & Gender & $\begin{array}{l}\text { Age } \\
\text { (years) }\end{array}$ & Diagnoses & $\begin{array}{l}\text { Current } \\
\text { employment } \\
\text { status }\end{array}$ \\
\hline Adrian & Male & 25 & mild ID & Unemployed \\
\hline Anna & Female & 32 & $\begin{array}{l}\text { mild ID, visual } \\
\text { impairment }\end{array}$ & $\begin{array}{l}\text { Employed (food } \\
\text { service) }\end{array}$ \\
\hline Maria & Female & 24 & $\begin{array}{l}\text { mild ID, Down } \\
\text { syndrome }\end{array}$ & $\begin{array}{l}\text { Employed (food } \\
\text { service) }\end{array}$ \\
\hline Oskar & Male & 35 & $\begin{array}{l}\text { Epilepsy, memory } \\
\text { deficits as a result of a } \\
\text { stroke in his early } \\
\text { twenties, intellectually } \\
\text { functioning on mild ID } \\
\text { level }\end{array}$ & $\begin{array}{l}\text { Employed } \\
\text { (office) }\end{array}$ \\
\hline Paula & Female & 26 & mild ID & $\begin{array}{l}\text { Employed (food } \\
\text { service) }\end{array}$ \\
\hline Robert & Male & 26 & $\begin{array}{l}\text { mild ID, physical } \\
\text { disability, articulation } \\
\text { difficulties }\end{array}$ & Unemployed \\
\hline
\end{tabular}

\section{Data Analysis}

The method employed for data analysis was IPA, and the analysis aimed at conforming to the guidelines developed by Smith and colleagues (1999). The steps taken to distinguish the emerging themes were as follows:

1. Each individual interview transcript was printed out.

2. The first three readings of one interview concentrated on making notes about interesting topics and writing down comments. The second and third reading aimed at generating relevant theme titles to be listed.

3. The emerging themes were listed on a separate piece of paper. 
4. Themes were reviewed and clustered together when similar.

5. The text was read through to discover whether the themes were relevant to the participants' views.

6. A table of emerging themes was prepared with references to particular fragments of the text.

7. The process was repeated for the next five interviews.

8. A final list of themes was prepared and similar themes were aggregated.

9. A final read of all interviews, focusing on the relevance of themes assigned to the quotations, was performed.

During the process, 33 fragments of interest illustrating the emerging themes were highlighted. Six themes emerged from the IPA analysis:

1. Motivation to become a social educator.

2. Being a social educator as an opportunity to gain practical skills.

3. Being a social educator as an opportunity to raise public awareness about disability.

4. Difficulties of being a social educator and ways to overcome them.

5. Personal value of being a social educator.

6. Readiness to recommend taking up the role of social educator to other people with disability.

All of the fragments of interest will be reported below in the Results section.

Afterwards, the transcripts were uploaded to ATLAS.ti 8 software (Hwang, 2008). Relevant quotations were assigned to the above themes (thematic codes). In order to maximize the objectivity of the assignments, two other independent raters (teachers working with students with ID) assigned specific quotations to the codes that emerged from the IPA procedure. The raters obtained a printed version of the complete transcripts of the interviews with 33 highlighted fragments of interest selected during the abovementioned process. At the head of the transcript, the thematic codes to which the raters were asked to assign the fragments were provided. Then, their ratings were entered into ATLAS.ti 8 and the agreement measures calculated using this software. The percentage agreement between the three raters was $96.6 \%$, Krippendorff's alpha 0.96 . 


\section{Ethics}

The study protocol was approved by the institutional research ethics committee at the University of Warsaw Faculty of Psychology. All of the participants provided informed, oral and written consent in easy to read language.

\section{Results}

Text in square brackets [] provides a part of the sentence which is not a direct quotation, but is contextual information necessary to understand the particular fragment.

\section{Motivation to Become a Social Educator}

Robert, Oskar, and Adrian received their invitation to participate in the project from its coordinators. Anna indicated that she had learned about the opportunity to become a social educator from her Organization colleagues. Overall, the data suggest that some of the interviewees decided to join the group responding to invitations from coordinators or friends. Although such a strategy is valuable and enabled the Organization to find self-advocates, it suggests that the project was rather an initiative of the professional staff than a grassroots activity. This may have affected the degree of real participation of people with ID and the way in which they perceived the project. That might have also limited the sense of responsibility for it among the people with ID who were involved.

For Oskar, participation in the project was a chance to express gratitude for what he had received from Organization:

[I became an educator] presumably because I belong to [the Organization], (...) that it helped me a lot and, (...), I want to give something, in return for how they helped me, as an Organization (...) and I want to somehow return the favor and show that I received something and I know that I received that (...) I can give something to others, not only being disabled, but also simply being a human. I know that someone gave me something, so I also know that I ought 
to return it. And I hope that I succeed in that, for instance, by the workshops. (Oskar)

The view expressed by Oskar suggests that self-advocacy had a strong meaning for him and was a way of realizing his need to give back what he received from the Organization. That might be viewed as evidence of a positive relationship between Oskar and the Organization, and that the activities offered by the Organization enabled people with a disability to feel as though they were real partners in the institutional life.

Maria became an educator out of curiosity, to see what it was like. She also preferred the "Let's do it together" meetings, where she could cooperate with the addressees of the workshop. Robert was also interested in getting to know new places and people. As a person with articulation and speech problems, he highlighted that he had no trouble with public appearances despite those impairments. Oskar indicated that the project is a valuable way of spending free time.

The motivations for joining the self-advocacy group included both the need for personal development and establishing relationships with others. The participation in the project was linked to an interest in experiencing something new and the need to fill free time. Such motivations suggest that participation in the project served as a form of pleasant and valuable activity.

\section{Being a Social Educator as an Opportunity to Gain Practical Skills}

Communication skills were an area of personal development indicated by participants as among the competences gained through participation in the project:

I am able to make a good decision fast, and also not keeping some bad emotions to myself, but speaking them out. (Maria)

I am becoming more open, courageous than I was, yeah, I feel understood by many people. (Robert)

It means, well, I speak less, I listen more. (Adrian)

I learned such openness, to talk about myself more, because before I was introverted, I didn't want to talk about it [my disability], I didn't 
want to talk at all. (...) I also learned to talk about my problems. If something is wrong, I tell the manager [at work], I don't keep it to myself. And I learn to be assertive, I talk about my feelings, what I reckon, and I don't judge other people. (Anna)

The respondents mentioned a variety of communication skills, encompassing both speaking out and being able to hold on and listen to other people. Both forms are important for being well-understood and establishing more satisfactory relationships with other people in one's personal and work life. The project was presumably an important starting point and a safe place for developing and exercising such skills.

Maria also indicated that the project gave her the opportunity to get to know new places and the city. Therefore, participation enabled her to become more independent and less afraid of moving around the big city.

Activity within the Organization was a unique chance for personal development, especially in the sphere of interpersonal communication. The possibility to self-advocate outside of the Organization, in an unknown, natural, but still safe environment brought an opportunity to develop within this particular area. These skills could then be used further in other life situations, such as in paid work.

\section{Being a Social Educator as an Opportunity to Raise Awareness about Disability}

Educators mentioned the chance to raise social awareness about disability as an important feature of being a self-advocate. Robert talked about the impact which anti-discriminatory education may have on young people and preparing them to be tolerant towards people with disability:

What is most important is teaching these young, healthy people, familiarize them with disability so that they won't perceive [badly] these people, won't laugh, insult or point fingers at them. (Robert)

Oskar indicated a similar aspect, also mentioning the fact that being an educator serves as a positive example of spending free time for young people:

I want to raise awareness of young people, mainly it concerns adolescents $(\ldots)$ show them that they can live in another way $(\ldots)$ 
that giving time to others, for example, I give such workshops, (...) they [the young people] take what I give to them and they don't necessarily lose that somewhere, but they can take this for the rest of their lives and show others, that they can be even better in the future than they are now. (...) I hand over this good energy and other generations will make use of this moment and will show that to other, future generations, that tolerance will be greater as well as disability awareness. (Oskar)

For Anna it was important to counter stereotypes about her disability:

I wanted to fight [stereotypes about] my disability, so that people know who a disabled person is. Because I work also to fight stereotypes. (...) [I work as an educator to] share as much knowledge as possible. (Anna)

The opinions of social educators indicate that their work provides a chance to change the social perception of people with disability. These opinions express a view that the project enhanced the empowerment of social educators, creating a space for them to become "experts about themselves". Such a feature of the project presumably empowers the self-advocates thanks to the fact that they feel influential, and that their voice might matter in the formation of attitudes of the audiences of their workshops.

\section{Difficulties of Being a Social Educator and Ways to Overcome them}

Social educators indicated various difficulties related to their activity, particularly difficulties stemming directly from their disability:

I am laughing, because in my case everything that is the most difficult is my head and my memory, because it's caused by my accident, meaning a stroke and... but regardless of that I don't give up, I try to remember (...). But mainly it is memory, because of which I, going to more workshops, am always afraid that I will forget what to do, what to say and so on, (...) these anxieties never turned out to be true. (Oskar)

I don't know how to say something, how to convey something, sometimes I'm not able to put something into a sentence. (Paula) 
It is hard to speak precisely. (Adrian)

Additionally, Maria indicated the difficulties she experienced during her first workshops. They were linked to the fact that the addressees of the workshops were prisoners:

[I conducted workshops] in a detention ward and that's how it [my activity as social educator] began, and I've liked conducting workshops since then. Before that, I never really conducted them here, in this institution [the Organization], it was a very nice experience, however there was a bit of adrenaline (laughing), you know why, it is a bit untypical, but it was worth it to go there and see how it is to conduct workshops. (Maria)

Paula mentioned her personality traits as constraints in being an educator:

I am a rather shy person in contact. I tried to approach others, I also try to work with that. And during [workshops] I have an opportunity to work, practice overcoming this difficulty. (Paula)

For Maria and Oskar, the presence of other people - social educators and coordinators - appeared to make it easier to overcome difficulties they experienced:

(...) I wasn't alone [during the workshops in the detention ward], so there were two people from Organization staff, so it wasn't that scary. (Maria)

And there are other educators who also support, we support each other during such workshops. (Oskar)

Public self-advocacy caused difficulties for the educators with which they surely struggled. However, they perceived conducting workshops as an opportunity for personal development. Moreover, the presence of supportive individuals and cooperation within the group were a crucial resource enabling them to face adversities head-on. It suggests that the self-advocacy project supported people in taking advantage of the group work, and probably facilitated learning to gain from the resources that a group provides. 


\section{Personal Value of Being a Social Educator}

Another theme that emerged from the interviews was the personal value which was ascribed by the educators to their work.

For Maria, the personal value of being a social educator was that she could talk about herself, but also learn how people with disability are perceived by the addressees of the workshops:

The most important? Above all to be myself, and to talk about my experiences, not the experiences of someone else. (...) [What is surprising in this work] is their [workshops participants'] knowledge, if there are people who know what disability is, for example they have a disabled person in the family (silence). And the approach towards disabled people, in general, that they don't shout, don't run away. (...) I could feel how they view disability and how, whether they can talk about it, that they don't feel difficulty or annoyance if they have to talk about it. (Maria)

Thanks to the project, Oskar was able to learn how people differ.

Surely I learned a lot about people, that everyone is different and it's cool, interesting, and beautiful. (Oskar)

Moreover, participation in the project was an extraordinary chance for him to thrive, which arose when he was having a very difficult time in life.

I was in such a moment, you know, I didn't know what I would do with my life, what I would be doing, I was stuck with my problems, and the Organization really shows a way, a path which is to be taken by a person with disability, that it doesn't have to be simple classes, for example art classes or something else, but such a project. We go out to people, we show them our disability, our selves, really, our real selves, which can be shown, we can give more than is expected. (Oskar)

Oskar expressed a view that being a self-advocate helped him to bounce back from the difficulties he experienced and to feel dignified by showing his real self to the workshop audiences. The process he described might be 
viewed as exercising resilience - the ability to cope with stressful events and situations and recover from them.

Anna mentioned how important it was for her to be perceived through the lens of her personality traits rather than her disability. Moreover, a sense of being needed was of great prominence:

[It is important for me] that they perceive me as I am, and not only judge, because I am a person... (short silence), well, that I have a problem. And [it is important] to be needed. (Anna)

The interviews suggest that, for the social educators, participation in the project was not only a responsibility and/or job, but also an event in their life to which they assigned personal value, linked to having a new role, something other than a stereotypical one. It also enabled them to interact with other people, self-actualize, and feel needed, which presumably is very important for their self-esteem and success in personal and work contexts.

\section{Readiness to Recommend Taking Up Role of Social Educator to other People with Disability}

All of the respondents expressed readiness to recommend the job of a social educator to other people. One of the respondents stressed out the importance of consent of people with disability to participate:

I would recommend this job to these people [with disability], but these people need to really want that. Nothing by force, really, they need to consent and, above all, be ready for that. And think it over, whether they will cope with it. (Anna)

The opinions expressed by the educators suggest that the main reason for recommending the job to other people with disability is the meaning it might have to the educator. The participants highlighted, that participation in such project needs to be an independent decision of a person with disability. Such opinion indicates at a form of "perspective taking" in self-advocates - as activists and social educators they acknowledge that the others need to feel on their own that the work is suitable for them to really gain from it. 


\section{Discussion}

The aim of the study was to find out how self-advocates with mild ID perceive their work as social educators. The interviews indicated that the respondents held positive opinions about their role as a public self-advocate.

The Organization emphasizes that the appropriate motivation of educators to participate in the project is crucial for its success. As suggested by the interviews, the actions of the project coordinators were the main reason why the majority of educators decided to undertake this role. On the one hand, according to McNally (2003), one of the advantages of self-advocacy groups functioning in close contact with supporting institutions is the ease of participant recruitment and the availability of resources crucial to leading the group. A similar phenomenon can be observed in the Organization - the initiative to bring the group to life came from its employees, but the relationships that had been established prior to that facilitated the successful recruitment of educators. On the other hand, the closeness of cooperation between the self-advocates and the Organization (run by professionals) may have its drawbacks, especially in terms of group independence and autonomy (Goodley, 2000; 2005). It puts into question whether the aims of selfadvocacy are fully acknowledged within this particular project and therefore, whether the social educators fully benefit from their involvement in it beyond spending their leisure time actively and taking part in activities in which they learn useful skills, directed by others. Furthermore, the relationship between this self-advocacy group and the Organization might result in difficulty in providing critical feedback about its systemic practices of inclusion (Aspis, 1997; Goodley, 2000), especially to researchers from outside the Organization. A potential future direction for the Organization is to revise the aims of their project to involve the self-advocates more in the process of preparation and conduction of workshops so as to minimize the potential tokenism (Hutton et al., 2010). However, it should be noted that at the time of study conduction, the Organization had only two years of experience in running the project. Thus, the process of transferring responsibility to the self-advocates was ongoing, and its success should be reassessed in a follow up study. Moreover, the context of social acceptance of people with ID in Poland suggests that much is still to be done on the societal level with the acceptance of this minority group, as well as in believing in their capabilities (see Kowalska \& Winnicka, 2013; Maison \& Rudzińska-Wojciechowska, 
2011), which in turn can result in people with ID being unsure about the opportunities to initiate actions or participate fully in projects such as the one led by the Organization. The work of "social educators" can be a step towards a positive change, empowering the self-advocates themselves, as well as serving as an anti-discriminatory action.

The participation in the project created chances for personal development for the respondents. The educators mentioned the opportunity to open up and talk about themselves and their disability and, as a consequence, developing communication skills. According to the theoretical model of self-advocacy by Anderson \& Bigby (2017), changes in various life domains initiated by taking part in a self-advocacy movement may result in greater self-esteem and engagement of people with disability in their own lives. The greater opening of self is an element of establishing positive self-acceptance. Importantly, thanks to participation in the project, people with disability can feel understood and act as a role model. Similar results have been obtained in other studies on self-advocacy (Beart et al., 2004; Booth \& Booth, 1999; Clarke et al., 2015; Stalker, 1997) and were revealed in systematic reviews of the studies on psychological and social benefits of group self-advocacy to people with ID (Fenn \& Scior, 2019; Tilley et al., 2020). One of the respondents also mentioned that self-advocacy supported him in resilience and finding a way to solve his problems and to find his way as a person with a disability. Resilience is an important protective factor from negative consequences of stress (Luthar et al., 2000), and might be very relevant for people with ID, who are particularly vulnerable to stress due to the transition from adolescence to adulthood (Gillan \& Coughlan, 2010; Leonard et al., 2016) and often struggle with social rejection and loneliness (Gilmore \& Cuskelly, 2014; Kowalska \& Winnicka, 2013).

The self-advocates pointed towards opportunities to socialize with others and establish positive relationships (within the group and with the Organization staff). Positive relationships built thanks to self-advocacy can enhance the social (emotional and practical) support available to people with ID (Beart et al., 2004; Goodley et al., 2003). It can also result in enhanced social capital (Mineur et al., 2017). Thus, such activity brings not only possibilities to thrive personally, but also to enlarge the social network and maximize chances of receiving help when needed.

According to the interviews, self-advocacy contributes positively to the acquisition and development of skills that are useful at work and in everyday 
life. This takes place in safe but natural conditions. The self-advocates receive valuable support from other people with disability. According to the literature, such kind of support is an important factor influencing the creation of positive identity and coping in a self-advocacy group (Caldwell, 2011; Gilmartin \& Slevin, 2010).

The matter of raising disability awareness was a vital motive in the interviews with social educators. Education of younger generations and forming social attitudes were very important for social educators. While this is linked with the aims of self-advocacy themselves (Stuntzner \& Hartley, 2015), it is also consistent with Article 8 of the Convention on the Rights of Persons with Disabilities (UN, 2006) concerning the actions which need to be taken to raise awareness about the problems of people with disabilities. The project is a way of bringing this idea to life.

One strength of this study is that people with mild ID speak in their own voices about being a self-advocate. It provides data about raising awareness about disability among people without ID - performed by the best experts in ID, the self-advocates.

One of the limitations of the study is that it concentrates on a single selfadvocacy group, and only self-advocates were interviewed (the project did not comprise gathering opinions from for instance, the Organization staff). In addition, the research involved persons with mild intellectual disability only and did not include persons with more severe forms of intellectual disability. However, this group homogeneity might be seen as a strength of this research, considering the possibility to aggregate the opinions of one specific group with similar experiences, and the process of becoming selfadvocates was similar among all participants. The number of participants was relatively low; however, information about the opportunity to take part in the research was presented to all of the social educators taking part in the project. All of the people with intellectual disabilities from the self-advocacy group who consented to participate were interviewed and their opinions reported.

Future studies should be extended in terms of the ideas which emerged during the interviews. They also could be compared to the experiences of a different group of self-advocates, including an international and/or intercultural study designs. 


\section{Conclusion}

The conducted interviews serve as a form of partial confirmation of the theoretical model of self-advocacy suggested by Anderson \& Bigby (2017). Self-advocacy gave the respondents a chance to speak out and raise awareness about disability (acting as social educators), spend their time valuably, help other members of the group as well as the audiences of their workshops, and establish relationships. The benefits they reported encompassed the development of personal competences needed in everyday life and at work. However, the opportunity to have power and status in the group and, as a consequence, fully engage with the activity, were not strongly visible within the respondents. This serves as a future direction for the Organization - to involve the self-advocates more in the process of preparing the project, with the ultimate goal of transferring responsibility for the group's actions to its members.

\section{Funding}

The authors were beneficiaries of a grant no. POWR.04.01.00-00-IH05/16 awarded to the University of Warsaw Office of Career Services. The grant was co-financed by the European Social Fund. This study was conducted by researchers from the academia, who were not part of the project nor were they the designers of it. The authors were not funded nor remunerated by the Organization, and the idea for this research came from the authors themselves.

This work was also supported by the University of Warsaw, from the funds awarded by the Ministry of Science and Higher Education in the form of a subsidy for the maintenance and development of research potential in 2021 (501-D125-01-1250000 zlec. 5011000612).

\section{References}

Allport, G. (1954). The nature of prejudice. New York: Addison-Wesley Publishing.

Anderson, S., \& Bigby, C. (2017). Self-advocacy as a means to positive identities for people with intellectual disability: 'We just help them, be 
them really', Journal of Applied Research in Intellectual Disabilities, 30, 109-120. https://dx.doi.org/10.1111/jar.12223

Arscott, K., Dagnan, D., \& Kroese, B. S. (1998). Consent to psychological research by people with an intellectual disability. Journal of Applied Research in Intellectual Disabilities, 11(1), 77-83.

https://doi.org/10.1111/j.1468-3148.1998.tb00035.x

Aspis, S. (1997). Self-advocacy for people with learning difficulties: does it have a future? Disability \& Society, 12(4), 647-654. https://doi.org/10.1080/09687599727182

Azzopardi-Lane, C., \& Callus, A. M. (2015). Constructing sexual identities: people with intellectual disability talking about sexuality. British Journal of Learning Disabilities, 43(1), 32-37. https://dx.doi.org/10.1111/bld.12083

Beail, N., \& Williams, K. (2014). Using qualitative methods in research with people who have intellectual disabilities. Journal of Applied Research in Intellectual Disabilities, 27(2), 85-96.

https://dx.doi.org/10.1111/jar.12088

Beart, S., Hardy, G., \& Buchan, L. (2004). Changing selves: a grounded theory account of belonging to a self-advocacy group for people with intellectual disabilities. Journal of Applied Research in Intellectual Disabilities, 17(2), 91-100. https://dx.doi.org/10.1111/j.13602322.2004.00186.x

Beckwith, R. M., Friedman, M. G., \& Conroy, J. W. (2016). Beyond tokenism: People with complex needs in leadership roles: A review of the literature. Inclusion, 4(3), 137-155. https://doi.org/10.1352/23266988-4.3.137

Binder, J., Zagefka, H., Brown, R., Funke, F., Kessler, T., Mummendey, A., Maquil, A., Demoulin, S., Leyens, J. P. (2009). Does contact reduce prejudice or does prejudice reduce contact? A longitudinal test of the contact hypothesis among majority and minority groups in three European countries. Journal of Personality and Social Psychology, 96(4), 843-856. https://dx.doi.org/10.1037/a0013470

Booth, T., \& Booth, W. (1999). Parents together: Action research and advocacy support for parents with learning difficulties. Health \& Social Care in the Community, 7(6), 464-474.

https://doi.org/10.1046/j.1365-2524.1999.00214.x 
Caldwell, J. (2011). Disability identity of leaders in the self-advocacy movement. Intellectual and Developmental Disabilities, 49(5), 315326. https://dx.doi.org/10.1352/1934-9556-49.5.315

Clarke, R., Camilleri, K., \& Goding, L. (2015). What's in it for me? The meaning of involvement in a self-advocacy group for six people with intellectual disabilities. Journal of Intellectual Disabilities, 19(3), 230-250. https://doi.org/10.1177/1744629515571646

Degener, T. (2016). Disability in a human rights context. Laws, 5(3), 35. https://doi.org/10.3390/laws5030035

Downing, J.A., Earles-Vollrath, T.L., \& Schreiner, M.B. (2007). Effective self-advocacy: what students and special educators need to know. Intervention in School and Clinic, 42(5), 300-304. https://dx.doi.org/10.1177/10534512070420050701

Fenn, K., \& Scior, K. (2019). The psychological and social impact of selfadvocacy group membership on people with intellectual disabilities: A literature review. Journal of Applied Research in Intellectual Disabilities, 32(1), 1349-1358. https://dx.doi.org/10.1111/jar.12638

Firkowska-Mankiewicz, A., \& Szeroczyńska, M. (2009). Impact of Social Advocacy on Updating Incapacity Determination Procedures for People With Intellectual Disabilities in Poland. Journal of Policy and Practice in Intellectual Disabilities, 6(3), 219-228. https://doi.org/10.1111/j.1741-1130.2009.00208.x

Friedman, M. G., Beckwith, R. M., \& Conroy, J. W. (2016). Inclusion is transformative: Self-advocacy leaders' perspectives on board inclusion and tokenism. Inclusion, 4(3), 183-190. https://doi.org/10.1352/23266988-4.3.183

Gillan, D., \& Coughlan, B. (2010). Transition from special education into postschool services for young adults with intellectual disability: Irish parents' experience. Journal of Policy and Practice in Intellectual Disabilities, 7(3), 196-203. https://doi.org/10.1111/j.17411130.2010.00265.x

Gilmartin, A., \& Slevin, E. (2010). Being a member of a self-advocacy group: experiences of intellectually disabled people. British Journal of Learning Disabilities, 38(3), 152-159.

https://dx.doi.org/10.1111/j.1468-3156.2009.00564.x

Gilmore, L., \& Cuskelly, M. (2014). Vulnerability to loneliness in people with intellectual disability: An explanatory model. Journal of Policy 
26 Nowakowska \& Pisula - Self-Advocates with Intellectual Disability

and Practice in Intellectual Disabilities, 11(3), 192-199.

https://doi.org/10.1111/jppi.12089

Goodley, D. (2000). Self-advocacy in the lives of people with learning difficulties: The politics of resilience. Buckingham: Open University Press.

Goodley, D. (2005). Empowerment, self-advocacy and resilience. Journal of Intellectual Disabilities, 9(4), 333-343.

https://doi.org/10.1177/1744629505059267

Goodley, D. (2011) Disability studies: An interdisciplinary introduction. Thousand Oaks: Sage Publications.

Goodley, D., Armstrong, D., Sutherland, K., \& Laurie, L. (2003). Selfadvocacy,"learning difficulties," and the social model of disability. Mental Retardation, 41(3), 149-160. https://doi.org/10.1352/0047-6765(2003)41<149:SLDATS > 2.0.CO;2

Hall, E. (2005). The entangled geographies of social exclusion/inclusion for people with learning disabilities. Health \& Place, 11(2), 107-115. https://dx.doi.org/10.1016/j.healthplace.2004.10.007

Henderson, D., \& Bigby, C. (2016). 'We were more radical back then':

Victoria's first self-advocacy organisation for people with intellectual disability. Health and History, 18(1), 42-66.

https://dx.doi.org/10.5401/healthhist.18.1.0042

Hollomotz, A. (2018). Successful interviews with people with intellectual disability. Qualitative Research, 18(2), 153-170. https://dx.doi.org/10.1177/1468794117713810

Hutton, S., Park, P., Park, R., \& Rider, K. (2010). Rights, respect and tokenism: Challenges in self-advocacy. Journal on Developmental Disabilities, 16(1), 109-113.

Hwang, S. (2008). Utilizing qualitative data analysis software: A review of Atlas.ti. Social Science Computer Review, 26(4), 519-527. https://dx.doi.org/10.1177/0894439307312485

Iacono, T. (2006). Ethical challenges and complexities of including people with intellectual disability as participants in research. Journal of Intellectual and Developmental Disability, 31(3), 173-179. https://dx.doi.org/10.1080/13668250600876392

Jaglińska, A. (2018). Osoby z niepełnosprawnościami jako edukatorzy społeczni w zakresie tematyki związanej z niepełnosprawnością - z doświadczeń Stowarzyszenia Otwarte Drzwi w realizacji projektu Siła 
Woli" [People with disabilities as social educators about disabilityrelated topics: experiences of Open Door Association in Willpower project realization]. In: J. Kowalska, R. Dziurla, \& K. BargielMatusiewicz (eds.), Kultura a zdrowie i niepetnosprawność (pp. 203224). Warsaw, Poland: Wydawnictwa Uniwersytetu Warszawskiego. Kanter, R. M. (1977). Some effects of proportions on group life: Skewed sex ratios and responses to token women. American Journal of Sociology, 82, 965-990.

Kowalska, J., \& Winnicka, J. (2013). Attitudes of undergraduate students towards persons with disabilities; the role of the need for social approval. Polish Psychological Bulletin, 44(1), 40-49. https://dx.doi.org/10.2478/ppb-2013-0005

Krippendorff, K. (2018). Content analysis: An introduction to its methodology. Thousand Oaks, CA: Sage Publications.

Leonard, H., Foley, K. R., Pikora, T., Bourke, J., Wong, K., McPherson, L., ... \& Downs, J. (2016). Transition to adulthood for young people with intellectual disability: the experiences of their families. European Child \& Adolescent Psychiatry, 25(12), 1369-1381. https://doi.org/10.1007/s00787-016-0853-2

Luthar, S., Cicchetti, D., \& Becker, B. (2000). The construct of resilience: A critical evaluation and guidelines for future work. Child Development, 71(3), 543-562. https://doi.org/10.1111/1467-8624.00164

Maison, D., \& Rudzińska-Wojciechowska, J. (2011). Obraz osób niepełnosprawnych intelektualnie oraz możliwości jego zmiany poprzez oddziaływanie kampanii społecznych [The image of persons with intellectual disability and the possibilities of its change by infl uence of public campaigns]. In: E. Pisula, K. Bargiel-Matusiewicz \& K. Walewska (Eds.), Oblicza rehabilitacji (pp. 15-40). Warszawa: Medipage.

McNally, S. (2003). A survey of self-advocacy groups for people with learning disabilities in an English region. Journal of Intellectual Disabilities, 6, 185-199.

https://dx.doi.org/10.1177/146900470200600207

Mineur, T., Tideman, M., \& Mallander, O. (2017). Self-advocacy in Sweden - an analysis of impact on daily life and identity of selfadvocates with intellectual disability. Cogent Social Sciences, 3(1), 1304513. https://doi.org/10.1080/23311886.2017.1304513 
Monteleone, R., \& Forrester-Jones, R. (2017). 'Disability Means, um, Dysfunctioning People': A qualitative analysis of the meaning and experience of disability among adults with intellectual disabilities. Journal of Applied Research in Intellectual Disabilities, 30(2), 301315. https://dx.doi.org/10.1111/jar.12240

Nirje, B. (1972). The right to self-determination. In: W. Wolfensberger (ed.), Normalization: The principle of normalization in human services, (pp. 176-200). Toronto, Canada: National Institute on Mental Retardation.

Nota, L., Ferrari, L., Soresi, S., \& Wehmeyer, M. (2007). Selfdetermination, social abilities and the quality of life of people with intellectual disability. Journal of Intellectual Disability Research, 51(11), 850-865. https://dx.doi.org/10.1111/j.13652788.2006.00939.x

Pennell, R. L. (2001). Self determination and self-advocacy: shifting the power. Journal of Disability Policy Studies, 11(4), 223-227. https://doi.org/10.1177/104420730101100404

Petri, G., Beadle-Brown, J., \& Bradshaw, J. (2017). "More Honoured in the Breach than in the Observance" - Self-Advocacy and Human Rights. Laws, 6(4), 26. https://doi.org/10.3390/laws6040026

Rose, J., Malik, K., Hirata, E., Roughan, H., Aston, K., \& Larkin, M. (2019). Is it possible to use interpretative phenomenological analysis in research with people who have intellectual disabilities?. Journal of Applied Research in Intellectual Disabilities, 32, 1007-1017. https://dx.doi.org/10.1111/jar.12605

Ryan, T. G., \& Griffiths, S. (2015). Self-advocacy and its impacts for adults with developmental disabilities. Australian Journal of Adult Learning, 55(1), 31-53.

Smith, J.A., Flowers, P., \& Larkin, M. (2009). Interpretative phenomenological analysis: Theory, method, research. London, United Kingdom: Sage.

Smith, J.A., Jarman, M., \& Osborn M. (1999). Doing interpretative phenomenological analysis. In: M. Murray, K. Chamberlain (Eds.). Qualitative health psychology. London, United Kingdom: Sage.

Stalker, K. (1997). Choices and voices: a case study of a self-advocacy group. Health \& Social Care in the Community, 5(4), 246-254. https://dx.doi.org/10.1111/j.1365-2524.1997.tb00120.x 
Stuntzner, S., \& Hartley, M. T. (2015). Balancing self-compassion with selfadvocacy: a new approach for persons with disabilities. http://selfcompassion.org/wp-content/uploads/2015/08/Stuntzner_Hartley.pdf

Test, D. W., Fowler, C. H., Wood, W. M., Brewer, D. M., \& Eddy, S. (2005). A conceptual framework of self-advocacy for students with disabilities. Remedial and Special Education, 1, 43-54. https://dx.doi.org/10.1177/07419325050260010601

Tilley, E., Strnadová, I., Danker, J., Walmsley, J., \& Loblinzk, J. (2020). The impact of self-advocacy organizations on the subjective wellbeing of people with intellectual disabilities: A systematic review of the literature. Journal of Applied Research in Intellectual Disabilities. https://doi.org/10.1111/jar.12752

United Nations (2006). Convention on the rights of persons with disabilities. https://www.un.org/development/desa/disabilities/convention-on-therights-of-persons-with-disabilities/convention-on-the-rights-ofpersons-with-disabilities-2.html

Walmsley, J., \& Central England People First History Project Team (2014). Telling the history of self-advocacy: A challenge for inclusive research. Journal of Applied Research in Intellectual Disabilities, 27(1), 34-43. https://doi.org/10.1111/jar.12086

Wehmeyer, M. L., \& Garner, N. W. (2003). The impact of personal characteristics of people with intellectual and developmental disability on self-determination and autonomous functioning. Journal of Applied Research in Intellectual Disabilities, 16(4), 255-265. https://dx.doi.org/10.1046/j.1468-3148.2003.00161.x

Wullink, M., Widdershoven, G., Van Schrojenstein Lantman-de Valk, H., Metsemakers, J., \& Dinant, G. J. (2009). Autonomy in relation to health among people with intellectual disability: a literature review. Journal of Intellectual Disability Research, 53(9), 816-826. https://dx.doi.org/10.1111/j.1365-2788.2009.01196.x

Żyta, A., \& Ćwirynkało, K. (2016). Self-advocates with intellectual disabilities in Poland and their way to social participation. 2nd International Conference on Lifelong Education and Leadership for All. Liepaja, Latvia.

https://www.researchgate.net/publication/312038613_SelfAdvocates_With_Intellectual_Disabilities_In_Poland_And_Their_Wa y_To_Social_Participation 
30 Nowakowska \& Pisula-Self-Advocates with Intellectual Disability

Iwona Nowakowska is a PhD Candidate at the Institute of Psychology at Maria Grzegorzewska University, Poland.

Ewa Pisula is a Professor at the Faculty of Psychology at University of Warsaw, Poland.

Contact Address: Iwona Nowakowska, Maria Grzegorzewska University, Institute of Psychology, Szczęśliwicka 40, 02-353 Warszawa, Poland. Email: insd2@aps.edu.pl 